\title{
Genetic Variation at Microsatellite Loci in Odorrana hosii (Boulenger, 1891)
}

\author{
DJONG HON TJONG*, ANUGRAH VIONA AGESI, DEWI IMELDA ROESMA \\ Department of Biology, Faculty of Mathematics and Natural Science, Andalas University \\ ${ }^{1}$ Limau Manis, Kota Padang, West Sumatera, Indonesia. 25175 \\ *Email: djonghontjong@sci.unand.ac.id
}

Received 9 March 2020; Received in revised form 30 April 2020;

Accepted 17 May 2020; Available online 30 June 2020

\begin{abstract}
The true frog species, Odorrana hosii, found in West Sumatera Indonesia, has high morphological differentiation and also estimated has high genetic variation. A total of $35 \mathrm{O}$. hosii at a seven location have analyzed using DNA microsatellite markers. Genetic variation of five microsatellite loci provided the highest value of expected heterozygosity $\left(H_{e}\right)$ for the population in Padang $\left(H_{e}=0.618\right)$, while the lowest was the population in Merapi $\left(H_{e}=0.427\right)$. There are genetic differences in moderate levels among populations of $O$. hosii in West Sumatra $\left(F_{S T}=0.108\right)$ with inbreeding intrapopulation value $\left(F_{I S}=-0.559\right)$, and high value of gene flow among the populations $(\mathrm{Nm}=2.061)$. This study becomes the first molecular data for establishing effective population management conservation.
\end{abstract}

Keywords: gene flow; heterozygosity; Odorrana hosii; poisonous rock-frog; Ranidae

\section{INTRODUCTION}

The distribution of Odorrana hosii is wide, from Thailand, Malay Peninsula, Sumatra, Java, to Borneo. This species can live in an altitude interval from 300 masl to 1430 masl. The widespread and the altitude interval for survival provide a possibility of morphological and genetic variation to $O$. hosii (van Kampen, 1923; Inger et al., 2017).

According to a previous study, $O$. hosii in West Sumatra from different altitudes interval shows a high morphological differentiation and variation to the relative length of chromosomes (Agesi, 2011). Several environmental factors affected differentiation in phenotypes, such as temperature and altitude, genetic factor, or interaction of both factors (Conover \& Schultz, 1995; Vences et al., 2002). Therefore, further research is necessary to examine the DNA level among $O$. hosii in West Sumatra to describe the species morphological variation that also happens genetically. This research aimed to analyze the genetic variation level of the $O$. hosii population in West Sumatra based on microsatellite markers. DNA Microsatellite markers are used because of these markers have a high polymorphism level. Hence, it is very appropriate to determine the genetic variation level within and between populations (Allendorf et al., 2012). Besides, the analysis of DNA variation using DNA microsatellite can also determine the genetic differentiation of a frog population-based on geographical location with a range of 10 kilometers (Morgan et al., 2008).

\section{MATERIALS AND METHODS}

The samples were collected at seven sites in West Sumatra (Alahan Panjang, Padang, Pasaman, Palupuah, Payakumbuh, Gunung Merapi, and Sijunjung). Those locations have been chosen based on altitude and distance shown in Figure 1 and Table 1.

DNA isolation. Analysis of genetic variation used DNA microsatellite markers (Funk et al., 2005; Arruda et al., 2017). DNA isolated from the liver tissue of five individuals from each population using QIAGEN kit protocol DNAeasy® Blood and Tissue Kit. PCR reaction was performed using PROMEGA PCR Core kit by mixing $2 \mu$ isolate DNA, 12 $\mu \mathrm{l}$ GoTaq Green Master Mix, $1 \mu$ forward primer, $1 \mu \mathrm{l}$ reverse primer, and sterile water until the total volume is $25 \mu \mathrm{l}$. All loci have an optimal temperature. Information of nine microsatellite loci showed in Table 2 . Amplification of DNA was programmed with an initial denaturation $95^{\circ} \mathrm{C}$ for $2 \mathrm{~min}, 33$ cycles of denaturation: $95^{\circ} \mathrm{C}$ for $30 \mathrm{~s}$, annealing: at optimal temperature $30 \mathrm{~s}$, extension: $72^{\circ} \mathrm{C}$ for $30 \mathrm{~s}$, and final extension $72^{\circ} \mathrm{C}$ for $5 \mathrm{~min}$. The product was detected by electrophoresis in 
agarose gel (1.2\% of DNA isolation and $2 \%$ of the PCR product).

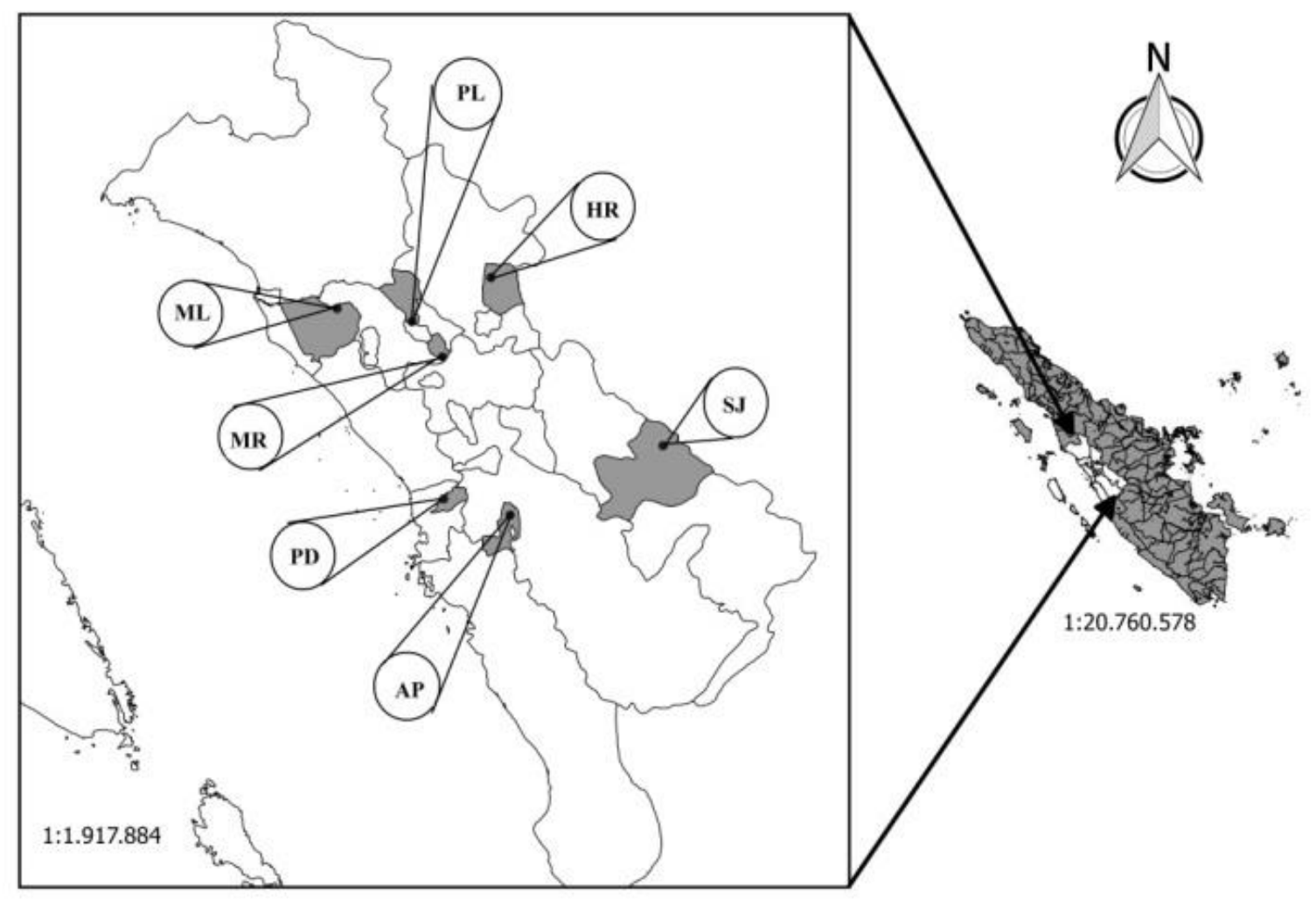

Figure 1. Research sites of Odorrana hosii in West Sumatra

Data analysis. Quantification of the results analyzed using the GENEPOP version 4.0 to determine the genetic variation within and between populations. The parameters used to determine the genetic variation within a population were allele frequencies, the percentage of polymorphic loci $\left(P_{p}\right)$, the average number of alleles per locus $\left(N_{a}\right)$, and expected heterozygosity $\left(H_{e}\right)$. Genetic variation between populations can be seen from the Fstatistic, genetic distance and similarity values dendrogram based on Nei's genetic distance matrix (1978) and the value of gene flow (Nm)(Raymond \& Rousset, 1995).

Table 1. Geographic position and attitude of research sites of $O$. hosii

\begin{tabular}{|c|c|c|c|c|}
\hline No. & Location & District & $\begin{array}{l}\text { Altitude } \\
\text { (m a.s.l) }\end{array}$ & Geographic Position \\
\hline 1 & Alahan Panjang & Solok & $1200-1400$ & $1^{\circ} 08^{\prime} \mathrm{SL}$ and $100^{\circ} 07^{\prime} \mathrm{EL}$ \\
\hline 2 & $\begin{array}{l}\text { Cagar Alam Lembah Harau- } \\
\text { Payakumbuh }\end{array}$ & 50 Kota & $500-600$ & $0^{\circ} 04^{\prime} \mathrm{SL}$ and $100^{\circ} 39^{\prime} \mathrm{EL}$ \\
\hline 3 & $\begin{array}{l}\text { Cagar Alam Malampah-Pasaman } \\
\text { Barat }\end{array}$ & Pasaman Barat & $456-763$ & $0^{\circ} 11^{\prime} \mathrm{SL}$ and $100^{\circ} 04^{\prime} \mathrm{EL}$ \\
\hline 4 & $\begin{array}{l}\text { Hutan Pendidikan Penelitian Biologi } \\
\text { (HPPB) Unand Padang }\end{array}$ & Padang & $260-300$ & $0^{\circ} 21^{\prime} \mathrm{SL}$ and $100^{\circ} 46^{\prime} \mathrm{EL}$ \\
\hline 5 & Gunung Merapi & Agam & $900-1500$ & $0^{\circ} 22^{\prime} \mathrm{SL}$ and $100^{\circ} 28^{\prime} \mathrm{EL}$ \\
\hline 6 & Cagar Alam Pangean I-Sijunjung & $\begin{array}{l}\text { Sawahlunto } \\
\text { Sijunjung }\end{array}$ & $300-600$ & $0^{\circ} 90^{\prime} \mathrm{SL}$ and $101^{\circ} 50^{\prime} \mathrm{EL}$ \\
\hline 7 & Cagar Alam Batang Palupuah-Agam & Agam & $700-1000$ & $0^{\circ} 14^{\prime} \mathrm{SL}$ and $100^{\circ} 21^{\prime} \mathrm{EL}$ \\
\hline
\end{tabular}




\section{RESULT AND DISCUSSION}

Amplification results of nine loci showed that only five loci produce the amplicon $(R n h-$ 3, Rnh-9, Rnh-10, Rnh-12, and Rnh-13). The optimal temperature has been searched previously for the nine loci with different annealing temperatures. The annealing temperature for the five loci were modified from Gong et al. (2013) shown in Table 2.

Table 2. Nine primer pairs of microsatellite markers produces amplicons and annealing temperature

\begin{tabular}{|c|c|c|c|c|}
\hline Locus ID & $T_{a}$ & Repeat Motif & Primer Sequences (5'-3') & Amplicon \\
\hline Rnh-1 & - & $(\mathrm{TGC}) 7$ & $\begin{array}{l}\text { F:TGAAGTATTCAGGTACAACAGGT } \\
\text { R:GGGCCAAAAGAGAGGGT }\end{array}$ & $\mathrm{X}$ \\
\hline Rnh-2 & - & (TGC)4TGTG(GTT)3T & $\begin{array}{l}\text { F:GCTTCGGGCTATAAATCAAACA } \\
\text { R:GCCTGGCCGACTACACG }\end{array}$ & $\mathrm{X}$ \\
\hline Rnh-3 & 52 & $(\mathrm{AAC}) 7$ & $\begin{array}{l}\text { F:CCGGAAGGCAGTGGAGGACA } \\
\text { R:ATGGACATGCGGTGGGGTAGG }\end{array}$ & $\mathrm{V}$ \\
\hline Rnh-4 & - & $(\mathrm{GA}) 5$ & $\begin{array}{l}\text { F:CGCTTACTATGGGGGGATA } \\
\text { R:GCCTGAGAAGGGTGGTGCT }\end{array}$ & $\mathrm{X}$ \\
\hline Rnh-6 & - & $(\mathrm{AAC}) 5$ & $\begin{array}{l}\text { F:TCTCGGGAGGAAAGCAATGG } \\
\text { R:AAGGAGCCTGGGACTATGGTAAAC }\end{array}$ & $\mathrm{X}$ \\
\hline Rnh-9 & 59.5 & $(\mathrm{GCA}) 7$ & $\begin{array}{l}\text { F:GCACAGTTAGCGAGATGGA } \\
\text { R:CTCACTAGAGCTGGGTGGTAT }\end{array}$ & $\mathrm{V}$ \\
\hline Rnh-10 & 61 & $(\mathrm{GCT}) 6$ & $\begin{array}{l}\text { F:AGTGCAACATCAACTTGGGTG } \\
\text { R:GCAGAGTCGCTGTCGGGA }\end{array}$ & $\mathrm{V}$ \\
\hline Rnh-12 & 58.5 & $(\mathrm{AC}) 20$ & $\begin{array}{l}\text { F:ATGTTATTGAGCCCAGAG } \\
\text { R:GGTCAGCAGCAGGTAA }\end{array}$ & $\mathrm{V}$ \\
\hline Rnh-13 & 55.3 & $(\mathrm{GCA}) 5$ & $\begin{array}{l}\text { F:GATACGGGAGGCAAACG } \\
\text { R:TCCACAGCCCAGCACTC }\end{array}$ & $\mathrm{V}$ \\
\hline
\end{tabular}

Notes: $T_{a}=$ annealing temperature; $\mathrm{V}=$ amplicon produces; $\mathrm{X}=$ not amplicon produces

The number of alleles at each locus ranged from five to seven, with as much as 27 alleles and an average of 5.4 alleles per locus. All alleles microsatellite showed a high polymorphism with the percentage of polymorphic loci $\left(P_{p}\right)$ ranged from 75 (Rnh-13) to $100 \%(R n h-9)$. Analysis of genetic variation showed that population of Padang have a high genetic variation with 17 allele per locus, 0.618 expected heterozygosity $\left(H_{e}\right)$, Shannon Index of 1.00 , and $100 \%$ of polymorphic loci $\left(P_{p}\right)$, and Merapi have a lower $\left(N_{a}=11 ; H_{e}=0.427 ; I=\right.$ $\left.0.616 ; P_{p}=80 \%\right)($ Table 3$)$.

Table 3. Analysis of the genetic variation of $O$. hosii based on microsatellite DNA in seven populations

\begin{tabular}{clccc}
\hline No. & Population & $\boldsymbol{N}_{\boldsymbol{a}}$ & $\boldsymbol{H}_{\boldsymbol{e}}$ & $\boldsymbol{I}$ \\
\hline $\mathbf{1}$ & Padang & 17 & 0.618 & 1.000 \\
\hline $\mathbf{2}$ & Alahan Panjang & 13 & 0.529 & 0.767 \\
\hline $\mathbf{3}$ & Malampah & 13 & 0.533 & 0.783 \\
\hline $\mathbf{4}$ & Harau & 11 & 0.444 & 0.619 \\
\hline $\mathbf{5}$ & Palupuh & 13 & 0.596 & 0.846 \\
\hline $\mathbf{6}$ & Sijunjung & 12 & 0.520 & 0.733 \\
\hline $\mathbf{7}$ & Merapi & 11 & 0.427 & 0.616 \\
\hline & Mean & 12.86 & 0.524 & 0.766
\end{tabular}

Notes: $N_{a}=$ the number of alleles per locus; $H_{e}=$ expected heterozygosity; $I=$ the average of Shannon index

The high value of $H_{e}$ in Padang because of large population sizes. A large number of $O$. hosii populations were based on criteria of high-level occurrence of $O$. hosii whilst collecting samples. Environmental conditions supported the local adaptation of populations
(Arens et al., 2006; Alberto et al., 2013). It has known that Padang was likely to become the habitat of $O$. hosii. According to Iskandar (1998), O. hosii was likely to live on a clear and strong water stream and a river streamline in the primary forest. A large population will reduce 
the chances of inbreeding and increase random mating so that heterozygosity will also be increased (Cervantes et al., 2011; Frankham, 2015; Hedrick \& Garcia-Dorado, 2016).

The lowest $H_{e}$ value was found in the Merapi population. It can expect these values a small number of population, which will increase the occurrence of inbreeding (Frankham et al., 2002). Inbreeding associated with the loss of genetic variation, drift and less heterozygous levels related to the loss of some alleles and low levels of polymorphism. As a result, it would increase inbreeding depression (Arens et al., 2006; Taylor et al., 2010; Jamieson, 2011).

Inbreeding depression is mating between individuals from the same parental offspring, which produce offspring with lower live quality level (Arens et al., 2006). Besides, Allendorf et al. (2012) also stated that a low level of heterozygosity could reduce viability because most of the population recessive alleles were lethal. Lethal recessive alleles, predominantly covered by dominant alleles in a heterozygote locus, have a big opportunity to express in a few populations. The extinction will probably led faster in a small number of frog populations (Rog et al., 2013; Soto-Azat et al., 2013). The categorization of a population can be looked at from its frequency of occurrence. The frequency of occurrence of $O$. hosii from Merapi is relatively lower than another population.

Table 4. The value of F-statistik $\left(F_{S T}, F_{I S}, F_{I T}\right)$ and gene flow $(\mathrm{Nm})$

\begin{tabular}{ccccr}
\hline Samples number & $\boldsymbol{F}_{\boldsymbol{S T}}$ & $\boldsymbol{F}_{\boldsymbol{I S}}$ & $\boldsymbol{F}_{\boldsymbol{I T}}$ & $\boldsymbol{N m}$ \\
\hline $\mathbf{3 5}$ & 0.108 & -0.559 & -0.3904 & 2.061 \\
\hline Notes: $F_{S T}=$ coefficient of genetic differentiation; $F_{I T}=$ the total inbreeding value; $F_{I S}$ = inbreeding intra population; $N m=$ gene flow
\end{tabular}

$F_{S T}$ value (Table 4 ) can determine the level of genetic differentiation between the $O$. hosii population in West Sumatra. According to Wright (1938), there are four categories of $F_{S T}$ values that ranged from 0 to $0.05 ; 0.05-0.15$; $0.15-0.25$; and $>0.25$. Each showed a level of genetic differentiation, which indicated low, moderate, high, and very high genetic differentiation. Based on the statements above, we can conclude that $O$. hosii between populations in West Sumatra has genetic differentiation value that shows moderate genetic differentiation $\left(F_{S T}=0.108\right)$. From the $F_{S T}$ value, we can determine that $10.82 \%$ of total genetic variation is among populations, and $89.18 \%$ is within the population.
The $F_{I T}$ value that is less than 0 indicated that inbreeding in a population is low and random mating still occurs, so the probability for closely related species cross is low (Charlesworth \& Willis, 2009). It is also supported by the value $\mathrm{Nm}$ among populations $(2.061 ; N m \leq 0.5)$. Based on that value, we know the migration of individuals among the population of $O$. hosii in West Sumatra is high (Slatkin, 1981). According to the obtained value, it can be concluded that $O$. hosii among populations in West Sumatra does not have genetic differentiation significantly based on microsatellite DNA.

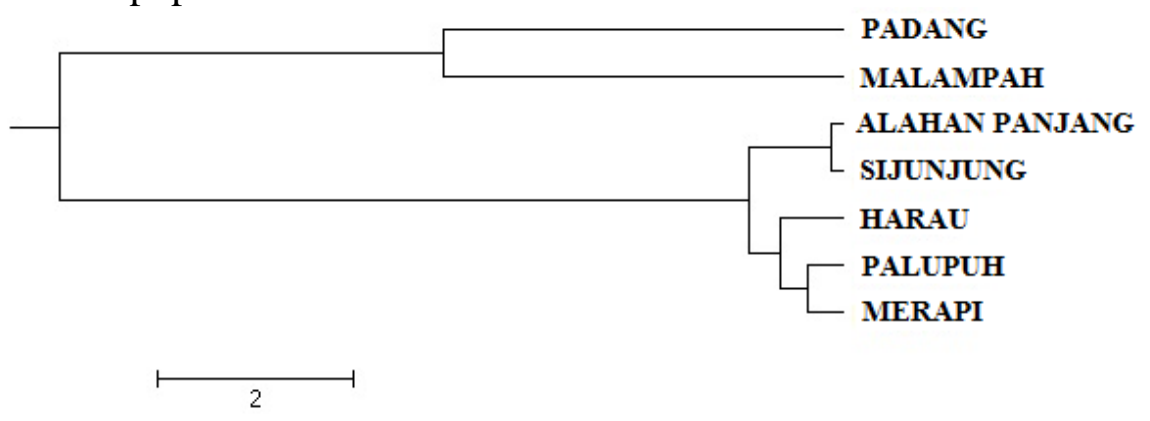

Figure 2. Dendogram of $O$. hosii population in West Sumatra by microsatellite markers 
The pattern of $O$. hosii grouping among populations is presented in the dendrogram (Figure 2). Based on the UPGMA cluster analysis, $O$. hosii grouping in West Sumatra is divided into two major groups and provides a unique grouping pattern. $O$. hosii populations form groups following Bukit Barisan highlands (Padang and Malampah populations create a group on the western side of Bukit Barisan highlands; Alahan Panjang, Sijunjung, Harau, Merapi, and Palupuah populations create a group on the eastern side of Bukit Barisan), as well as the existence of rivers that facilitate the migration of individuals among populations. $O$. hosii grouping based on UPGMA cluster analysis is supported by genetic distance value among populations (Table 5).

Table 5. Nei (1978) genetic distance matrix in seven populations of $O$. hosii based on microsatellite markers

\begin{tabular}{clccccccc}
\hline No. & \multicolumn{1}{c}{ Population } & $\mathbf{1}$ & $\mathbf{2}$ & $\mathbf{3}$ & $\mathbf{4}$ & $\mathbf{5}$ & $\mathbf{6}$ & $\mathbf{7}$ \\
\hline $\mathbf{1}$ & Padang & 0.000 & & & & & & \\
\hline $\mathbf{2}$ & Alahan Panjang & 0.070 & 0.000 & & & & & \\
\hline $\mathbf{3}$ & Malampah & 0.080 & 0.126 & 0.000 & & & & \\
\hline $\mathbf{4}$ & Harau & 0.094 & 0.014 & 0.134 & 0.000 & & & \\
\hline $\mathbf{5}$ & Palupuh & 0.144 & 0.027 & 0.227 & 0.017 & 0.000 & & \\
\hline $\mathbf{6}$ & Sijunjung & 0.127 & 0.002 & 0.240 & 0.038 & 0.009 & 0.000 & \\
\hline $\mathbf{7}$ & Merapi & 0.118 & 0.025 & 0.291 & 0.009 & 0.007 & 0.003 & 0.000 \\
\hline
\end{tabular}

Table 5 presents that several populations are showing the great value of genetic distance differences among the population. It is caused by factors such as geographical isolation in the form of physical barriers, environmental factor differences, and reproduction. One of those factors will affect genetic structure formation (Arioli et al., 2010; Fouquet et al., 2012; Twomey et al., 2016)). It can be concluded that geographical isolation factor, which is Bukit Barisan highlands locating from northern to the southern side of Sumatra that serves as a physical barrier separating among populations, has affected genetic structure formation of $O$. hosii.

\section{CONCLUSION}

The highest genetic variation of $O$. hosii is from the population in Padang $\left(N_{a}=17, H_{e}=\right.$ $0.618, I=1.000)$, while the lowest genetic variation is from the population in Merapi $\left(N_{a}\right.$ $\left.=11, H_{e}=0.427, I=0.616\right)$. The existence of Bukit Barisan Mountain potentially becomes a barrier as well as the classification of $O$. hosii in West Sumatra. The analysis of the population's genetic structure has shown a moderate genetic variation $\left(F_{S T}=0.108\right)$.

\section{ACKNOWLEDGEMENTS}

The authors would like to thanks the Research Grants Team from Postgraduate Andalas University No. 03/UN.16/PL.HP/2013 and research team colleagues: Putri Yuliatmy, Silvia Indra, Neqita Deliana Benita, Defli Haznan, Hadi Kurniawan, Rizky DB, Ari Arfhama, and Bambang Nurwansyah who helped to collect samples in seven locations, and also giving support from the beginning of this study until finished this manuscript.

\section{REFERENCES}

Agesi AV. 2011. Variasi Morfometri dan Kariotipe Rana hosii (Boulenger, 1891) di Sumatera Barat. [Skripsi]. Padang: Andalas University.

Alberto FJ, Aitken SN, Alía R, González-Martínez SC, Hänninen H, Kremer A, Lefêvre F, Lenormand T, Yeaman S, Whetten R, Savolainen O. 2013. Potential for evolutionary responses to climate change-evidence from tree populations. Global Change Biology. vol 19(6): 1645-1661. doi: https://doi.org/10.1111/gcb.12181.

Allendorf FW, Luikart GH, Aitken SN. 2012. Conservation and the genetics of populations. $2^{\text {nd }}$ ed. New Jersey: Wiley-Blackwell. pp. 34-73.

Arens P, Bugter R, van't Westende W, Zollinger R, Stronks J, Vos CC, Smulders MJM. 2006. Microsatellite variation and population structure of a recovering Tree frog (Hyla arborea L.) metapopulation. Conservation Genetics. vol 7: 
825-835. doi: https://doi.org/10.1007/s10592-0059112-7.

Arioli M, Jakob C, Reyer HU. 2010. Genetic diversity in water frog hybrids (Pelophylax esculentus) varies with population structure and geographic location. Molecular Ecology. vol 19(9): 1814-1828. doi: https://doi.org/10.1111/j.1365-294X.2010.04603.x.

Arruda MP, Costa WP, Recco-Pimentel SM. 2017. Genetic diversity of Morato's Digger Toad, Proceratophrys moratoi: spatial structure, gene flow, effective size and the need for differential management strategies of populations. Genetics and Molecular Biology. vol 40(2): 502-514. doi: https://doi.org/10.1590/1678-4685-gmb-20160025 .

Cervantes I, Goyache F, Molina A, Valera M, Gutiérrez JP. 2011. Estimation of effective population size from the rate of coancestry in pedigreed populations. Journal of Animal Breeding and Genetics. vol 128(1): 56-63. doi: https://doi.org/10.1111/j.1439-0388.2010.00881.x.

Charlesworth D, Willis JH. 2009. The genetics of inbreeding depression. Nature Reviews Genetics. vol 10(11): 783-796. doi: https://doi.org/10.1038/nrg2664.

Conover DO, Schultz ET. 1995. Phenotypic similarity and the evolutionary significance of countergradient variation. Trends in Ecology \& Evolution. vol 10(6): 248-252. doi: https://doi.org/10.1016/S0169-5347(00)89081-3.

Funk WC, Blouin MS, Corn PS, Maxell BA, Pilliod DS, Amish S, Allendorf FW. 2005. Population structure of Columbia spotted frogs (Rana luteiventris) is strongly affected by the landscape. Molecular ecology. vol 14(2): 483-496. doi: https://doi.org/10.1111/j.1365-294X.2005.02426.x.

Fouquet A, Ledoux JB, Dubut V, Noonan BP, Scotti I. 2012. The interplay of dispersal limitation, rivers, and historical events shapes the genetic structure of an Amazonian frog. Biological Journal of the Linnean Society. vol 106(2): 356-373. doi: https://doi.org/10.1111/j.1095-8312.2012.01871.x.

Frankham R. 1998. Inbreeding and extinction: island populations. Conservation Biology. vol 12(3): 665675. doi: https://doi.org/10.1111/j.15231739.1998.96456.x.

Frankham R, Ballou JD, Briscoe DA. 2002. Introduction to conservation genetics. Cambridge: Cambridge University Press. doi: https://doi.org/10.1017/CBO9780511808999.

Frankham R. 2015. Genetic rescue of small inbred populations: Meta-analysis reveals large and consistent benefits of gene flow. Molecular ecology. vol 24(11): 2610-2618. doi: https://doi.org/10.1111/mec.13139.

Gong J, Lan H, Fang SG, Wan QH. 2013. Development and characterization of 13 polymorphic microsatellite DNA markers for the pond green frog (Rana nigromaculata). Journal of Genetics. vol
92(1): 7-10. doi: https://doi.org/10.1007/s12041011-0004-y.

Hedrick PW, Garcia-Dorado A. 2016. Understanding inbreeding depression, purging, and genetic rescue. Trends in Ecology \& Evolution. vol 31(12): 940 952.

doi: https://doi.org/10.1016/j.tree.2016.09.005

Inger RF, Stuebing RB, Grafe U, Dehling JM. 2017. A Field Guide to the Frogs of Borneo. $3^{\text {rd }}$ ed. Kinabalu: Natural History Publications Borneo. p. 228.

Iskandar DT. 1998. The Amphibians of Java and Bali. Bogor: Research and Development Centre for Biology-LIPI. p. 117.

Jamieson IG. 2011. Founder effects, inbreeding, and loss of genetic diversity in four avian reintroduction programs. Conservation Biology. vol 25(1): 115123. doi: https://doi.org/10.1111/j.15231739.2010.01574.x.

Morgan MJ, Hunter D, Pietsch ROD, Osborne W, Keogh JS. 2008. Assessment of genetic diversity in the critically endangered Australian corroboree frogs, Pseudophryne corroboree and Pseudophryne pengilleyi, identifies four evolutionarily significant units for conservation. Molecular Ecology. vol 17(15): 3448-3463. doi: https://doi.org/10.1111/j.1365-294X.2008.03841.x.

Nei M. 1978. Estimation of average heterozygosity and genetic distance from a small number of individuals. Genetics. vol 89(3): 583-590.

Raymond M, Rousset F. 1995. GENEPOP (version 1.2): population genetics software for exact tests and ecumenicism. Journal of Heredity. vol 86(3): 248249.

Rog S, Ryan MJ, Mueller U, Lampert KP. 2013. Evidence for morphological and genetic diversification of túngara frog populations on islands. Herpetological Conservation and Biology. vol 8(1): 228-239.

Slatkin M. 1981. Estimating levels of gene flow in natural populations. Genetics. vol 99(2): 323-335.

Soto-Azat C, Valenzuela-Sánchez A, Collen B, Rowcliffe JM, Veloso, A, Cunningham AA. 2013. The population decline and extinction of Darwin's frogs. PLoS One. vol 8(6): 1-11. doi: https://dx.doi.org/10.1371\%2Fjournal.pone.00669 57.

Taylor SS, Sardell RJ, Reid JM, Bucher T, Taylor NG, Arcese P, Keller LF. 2010. Inbreeding coefficient and heterozygosity-fitness correlations in unhatched and hatched song sparrow nestmates. Molecular Ecology. vol 19(20): 4454-4461. doi: https://doi.org/10.1111/j.1365-294X.2010.04824.x.

Twomey E, Vestergaard JS, Venegas PJ, Summers K. 2016. Mimetic divergence and the speciation continuum in the mimic poison frog Ranitomeya imitator. The American Naturalist. vol 187(2): 205224. doi: https://doi.org/10.1086/684439.

van Kampen PN. 1923. The amphibia of the IndoAustralian archipelago. Leiden: EJ Brill. 
Vences M, Puente M, Nieto S, Vieites DR. 2002. Phenotypic plasticity of anuran larvae: environmental variables influence body shape and oral morphology in Rana temporaria tadpoles.
Journal of Zoology. vol 257(2): 155-162. doi:10.1017/S0952836902000754.

Wright S. 1938. Size of population and breeding structure in relation to evolution. Science. vol 87: 430-431. 